A

\title{
Rевевсн автіске: Development of leaf spot of safflower (Alternaria carthami) in relation to weather parameters
}

\author{
S.S. WAGH, A.P. SURYAWANSHI AND V.M. GHOLVE
}

Article Chronicle:

Received :

19.07.2017;

Accepted :

03.08.2017

SUMMARY : A field experiment was conducted successively for 2 years (2013-14 and 2014-15) with an objective to study the effect of different weather parameters viz., rainfall, temperature and humidity on the development of Alternaria leaf spot of safflower caused by Alternaria carthami. Correlation-coefficient studies revealed significantly and positively correlation between temperature (Max. and Min.), relative humidity (RH - I and RH - II) and rainfall with Alternaria blight disease intensity (during Rabi, 2013-14). Whereas, during Rabi, 2014-15, temperature (minimum), relative humidity (RH - I and RH - II) and wind velocity were positive and significantly correlated with the disease intensity.

How to cite this article : Wagh, S.S., Suryawanshi, A.P. and Gholve, V.M. (2017). Development of leaf spot of safflower (Alternaria carthami) in relation to weather parameters. Agric. Update, 12(TECHSEAR-7) : 19951999; DOI: 10.15740/HAS/AU/12.TECHSEAR(7)2017/1995-1999.

KEY Words:

Carthamus tinctorius L., Alternaria carthami, Correlation, Weather parameters

Author for correspondence :

\section{S.S. WAGH}

Department of Plant Pathology, College of Agriculture, Vasantrao Naik Marathwada Krishi Vidyapeeth, PARBHANI (M.S.) INDIA

Email : drwaghss@gmail. com

See end of the article for authors' affiliations 